\title{
AN INVESTIGATION INTO IMPROVING THE GERMINATION RATES OF ALOE POLYPHYLLA SCHÖNLAND EX PILLANS
}

\author{
Carl Berthold
}

\begin{abstract}
A germination technique trial was carried out to improve the germination of Aloe polyphylla Schönland ex Pillans (common name spiral aloe). These germination trials involved different media and temperatures, increased oxygen levels, and light and dark environments. The best results (90\% germination) were obtained by vernalising the seeds for two weeks and then placing them in a sunny, but not bright, area with varying temperatures on a water-based medium of either $10 \%$ recommended fertiliser solution or in distilled water.

The germination of Aloe polyphylla was also compared to three other species in the genus: A. branddraaiensis Groenew, A. castanea Schönl and A. elegans Tod.. The results from this trial showed that, like A. polyphylla, these species can also germinate in water-based media.

The success of finding the key requirements for germination show that techniques of this type are important methods for conserving this threatened species and can also be a useful propagation tool for the horticulture industry. The lack of research on this plant highlights the importance of this work for conserving this spectacular species which is listed as Vulnerable in the International Union for Conservation of Nature (IUCN) Plant Red Data list and is registered on the Convention on International Trade in Endangered Species of Wild Fauna and Flora (CITES).
\end{abstract}

\section{BACKGROUND}

The plan for this investigation came from a phone call to the seed distributor at the British Cacti and Succulent Society, Jeff Capel. At the time the author was searching for seeds for a previous BSc thesis project and Mr Capel had over 3,000 Aloe polyphylla seeds which he had recently acquired from a friend's plant in Coventry and was prepared to share. The offer to research and document a way to effectively propagate this endangered species was too good to resist. Mr Capel endorsed the plan and generously sent 2,000 seeds to the author to trial and test in return for the resulting plants and a copy of the thesis.

\section{INTRODUCTION}

Aloes belong to the family Asphodelaceae and are widespread in the Old World, primarily South Africa. Many species prefer arid habitats but some thrive in tropical and even high alpine regions, and A. polyphylla is one of these. Its classification is still being

1. Carl Berthold works with the plant database system at the Royal Botanic Garden Edinburgh. Address: 20A Inverleith Row, Edinburgh, EH3 5LR, UK.

Email: C.Berthold@rbge.ac.uk 


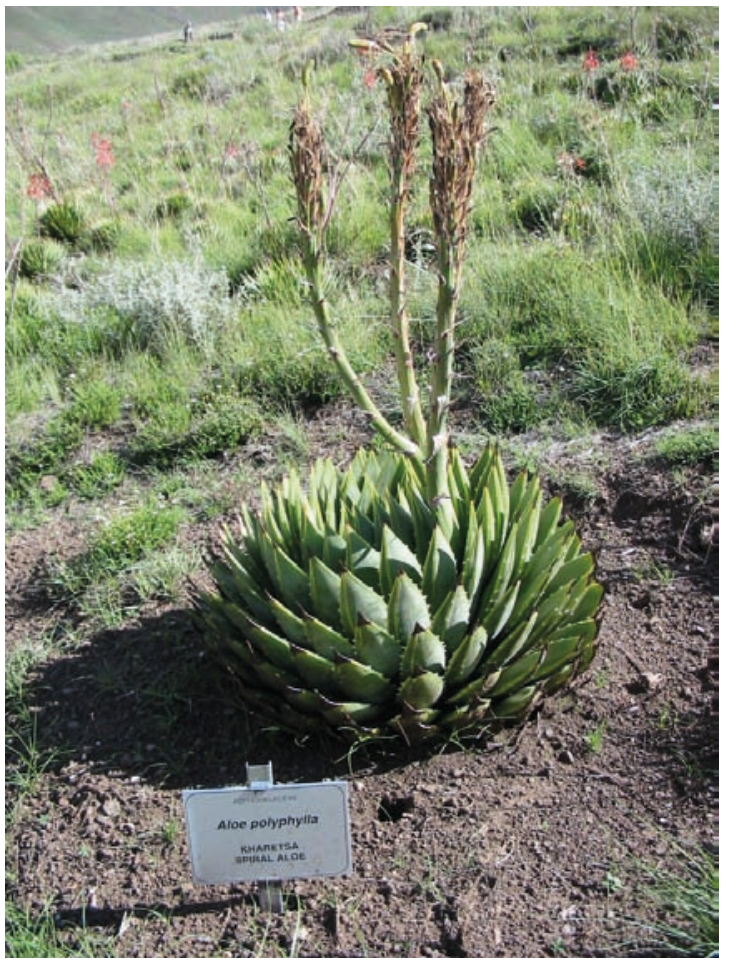

Fig. 1 Aloe polyphylla growing in cultivation in Katse Botanical Garden, Lesotho. Photo: Leigh Morris.

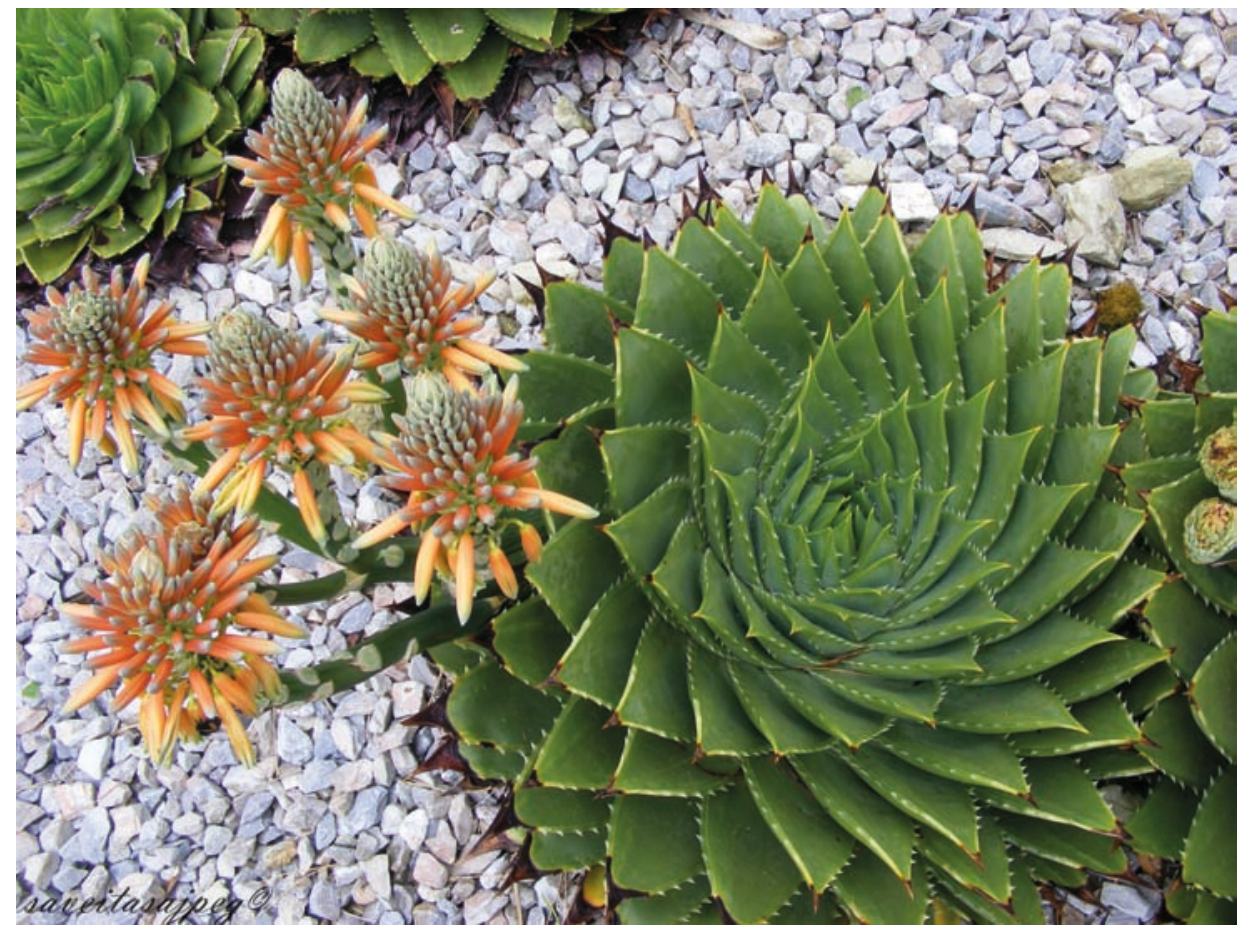

Fig. 2 Flowering A. polyphylla in cultivation. Photo: Peter Brew. 
debated as its relationship with other families is still unresolved and it is sometimes combined with Xanthorrhoeaceae (Heywood, 2007; Mabberley, 2008).

Aloe polyphylla was first described by Schönland of the Albany Museum in 1923 but the description was never validly published (Talukdar, 1983). N.S. Pillans eventually published a description based on Schönland's notes and data from T. Reynolds in 1934 (Pillans, 1934; Talukdar, 1983). Like all its succulent relatives, A. polyphylla is a perennial xerophyte (Reynolds, 2004). It is has broad, oblong, acuminate, grey-green leaves, $20-30 \mathrm{~cm}$ long and $6-10 \mathrm{~cm}$ broad, which are always arranged in five rows of fifteen to thirty leaves and with an anti-clockwise or clockwise twist (Beverly, 1979; Plantzafrica, 2002).

The species flowers from August to December, mainly in September and October (Jeppe, 1974) and has inflorescences reaching 50-60 cm high with three to eight branches from low down with several sterile bracts $2-3 \mathrm{~cm}$ long (Fig. 1). Perianth is cylindrictrigonous, slightly narrower low down, approximately $10 \mathrm{~mm}$ in diameter at the middle, slightly broader upwards, with mouth slightly upturned, pale red to salmon-pink, rarely yellow (Fig. 2); outer segments free to base, three-nerved. Anthers exerted 5mm. Stigma at length exerted 5mm (Beverly, 1979; Jeppe, 1974; Plantzafrica, 2002). It consists of about $95 \%$ water and, at maturity, has around 165 to 175 leaves (Beverly, 1998). A perennial xerophyte, it is characterised by its anti-clockwise or clockwise leaves which appear to twist out of the centre - hence the common name spiral aloe - which has made it a much sought-after plant. The plants have about 150 leaves each, which explains the specific epithet 'polyphylla', poly meaning many and phylla meaning leaves (Fig. 3).

Aloe polyphylla occurs at 500-2,400m in the Drakensberg Mountains and Maluti Mountains in Lesotho (Beverly, 1979; Glen et al., 2000). It grows in rich peaty soils, on steep basalt slopes with rosettes tilted sideways (Jeppe, 1974; Beverly, 1979).

According to Jeppe (1974), the climate in Lesotho is never hot. In summer it is mild and in winter it is often extremely cold with temperatures well below freezing, and the mountains are nearly always covered in snow. Summer is the rainy season, whereby annual rainfall is around 875 to $1,000 \mathrm{~mm}$ and plants receive even more moisture from cloud and mist at higher altitudes. Lesotho shares similar seasons with South Africa, which can be summarised as:

- Winter: from May to July;

- Summer: from mid-October to mid-February;

- Autumn: from mid-February to April;

- Spring: from August to mid-October.

\section{CONSERVATION}

Aloe polyphylla is listed as Vulnerable in the IUCN Red Data list and is registered on CITES appendix I. Julia \& Jiwen (2009) wrote a paper describing the current conservation status of this species in which they stated that the main threats were unsustainable 


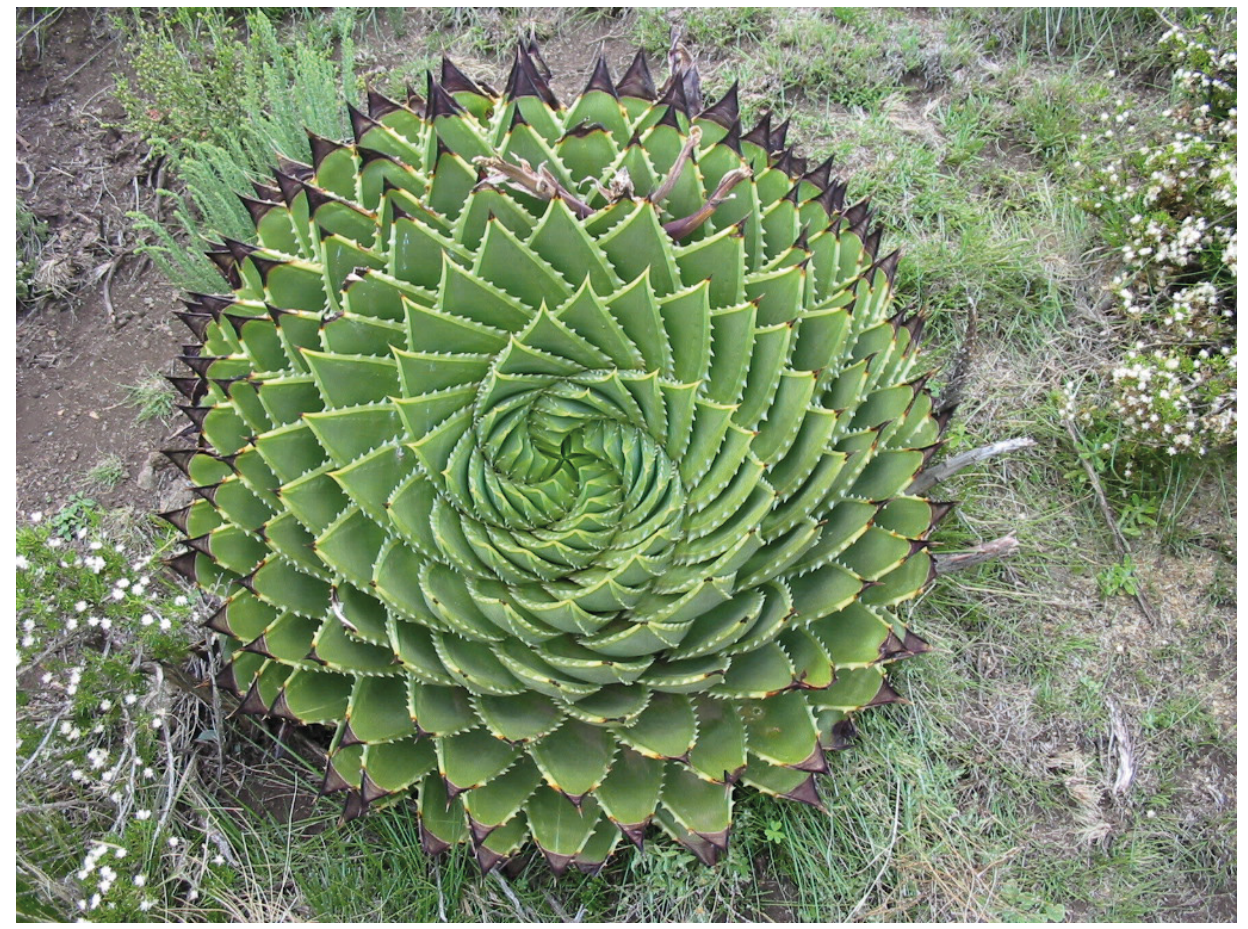

Fig. 3 A. polyphylla leaf spiral. Photo: Leigh Morris.

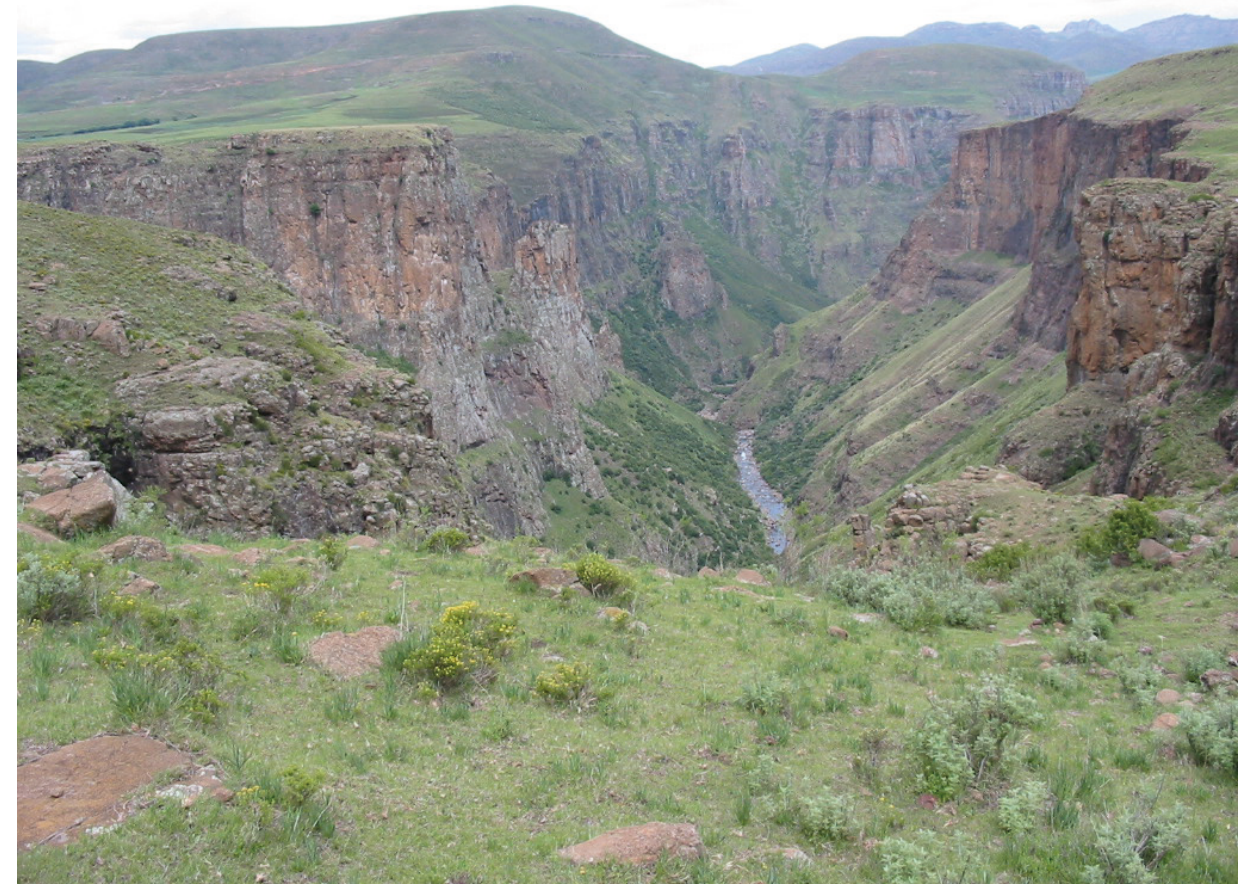

Fig. 4 Lesotho mountains and canyons. Many populations of A. polyphylla are now confined to inaccessible areas and the rugged topography is acting as a last barrier against collectors. Photo: Leigh Morris. 
harvesting by local communities (mostly as a medicinal plant), over-collection by plant enthusiasts, grazing and the increasing rarity of its pollinator, the malachite sunbird. Conservation efforts on this plant go back to 1938 with a law prohibiting its removal, export, sale or destruction. Since then that law has been replaced and improved in order to control the international traffic of this species. Ex situ cultivation of the species has reduced the pressure on the populations in the wild but the local communities still continue to harvest at an unsustainable rate as they are not aware of the importance of conserving it.

\section{RESEARCH INTO GERMINATION RATES OF ALOE POLYPHYLLA}

The only major pieces of work on the germination of A. polyphylla were carried out by Beverly (1998) and Jacot Guillarmod (1970). Beverly (1998) states that scarification by sanding of the outermost seed coat must be undertaken to the extent that it breaks off the outer wings and coat and that it should then be dried and cleaned. The seeds should then be sown at about $7.5 \mathrm{ml}$ per seed tray of $40 \times 40 \times 5 \mathrm{~cm}$ on a sterilised potting mix and the seed covered with $1.5 \mathrm{~mm}$ of soil and followed by light compaction until smooth. Seeds and seedlings should be misted 2-3 times daily in an environment with bottom heat at $25^{\circ} \mathrm{C}$. The estimated germination rate by this method is around $80 \%$ (Beverly, 1998). He also states that supplementary lighting helps for post-germination establishment and should be set at 15-hour day length.

The Jacot Guillarmod (1970) method for germination states that seeds should be given cold treatments (a household refrigerator is suitable - around $4^{\circ} \mathrm{C}$ ) overnight but preferably for longer. Her recommended method alternates cold and sunny window positions to produce the best results. The seeds should be placed on wet filter paper in Petri dishes but blotting paper, sterilised in an oven, can replace it. The water should be distilled but boiled water can also be used. Jacot Guillarmod (1970) estimates that over half the seeds should germinate with this method within two months.

The most recent work done on the propagation of A. polyphylla is by Bairu et al. (2007), which was by micropropagation. Other recent work includes micropropagation work carried out by Chukwujekwu, Fennell and van Staden (2002); Abrie and van Staden (2001); and Ramsay et al. (2000), all of which gave good results but which seemed to have great problems with keeping them alive after initial shooting. The trial carried out by Abrie et al. (2001) which set the seeds initially at $15^{\circ} \mathrm{C}$ gave no results but after increasing the temperature to $24^{\circ} \mathrm{C}$, germination occurred rapidly.

When considering conventional seed propagation methods, the most recent work done on this species dates back to 1998 and was carried out by Beverly (1998). A subsequent paper entitled 'Aloe polyphylla Schönland ex Pillans: The secrets for success' described a method he uses at his nursery to grow his A. polyphylla stock. 
MATERIALS AND METHODS

The trials carried out by the author used the following materials:

1. Distilled water (used as control and trial media)

2. Tap water obtained from University of Worcester science lab

3. $\operatorname{Vitax}^{\odot}\left(0.5 \mathrm{~g} \mathrm{l}^{-1} \mathrm{w} / \mathrm{v}\right)$ Cacti and Succulent Feed (shown as $100 \%$ fert. solution in trial), mixed in distilled water

4. $\operatorname{Vitax}^{\odot}\left(0.05 \mathrm{~g} \mathrm{l}^{-1} \mathrm{w} / \mathrm{v}\right)$ Cacti and Succulent Feed (shown as $10 \%$ fert. solution in trial), mixed in distilled water

5. Sphagnum moss with added $20 \mathrm{ml}$ of distilled water for moisture

6. John Innes Seed Sowing Compost

7. Silver sand with added $20 \mathrm{ml}$ of distilled water for moisture

8. Resealable clear plastic bags $(4.5 \times 4.5 \mathrm{~cm})$

Each bag was filled up to the bottom of the first label mark (liquid-based media measured to a volume of $40 \mathrm{ml}$ ).

The methods for adding fertilisers were as follows: 1 litre of distilled water was measured into a glass beaker and $0.5 \mathrm{~g}$ of the nutrient fertiliser was weighed on a balanced weighing machine. This was then added to the water and mixed with a glass rod until the fertiliser had dissolved. The concentrated solution was equivalent to the amount recommended by the manufacturer (labelled as 100\% fert.). Following this, $900 \mathrm{ml}$ of distilled water was measured into a glass beaker and $100 \mathrm{ml}$ of the solution above was added to create a $10 \%$ solution (labelled as $10 \%$ fert.).

Seeds were subjected to four temperatures to see whether this affected germination. These were $10^{\circ} \mathrm{C}, 15^{\circ} \mathrm{C}, 20^{\circ} \mathrm{C}$ and window temperature (min. $16^{\circ} \mathrm{C}$, max. $26^{\circ} \mathrm{C}$ ) in accordance with a trial undertaken by Chukwujekwu et al. (2002). For each of these four conditions one bag of each medium containing ten seeds was prepared. Overall nine trials were carried out in order to narrow down the optimum germination environment and yield. These are described below:

Trial 1: The aim of this trial was to find out which temperatures and media gave the best germination (the total number germinated) for A. polyphylla. This was a preliminary test which would then be brought forward to be used in further trials. Information on media and temperatures was obtained, and partially based on work carried out by Beverly (1998), Jacot Guillarmod (1969) and Horkwood (1966).

Trial 2: The aim of this trial was to demonstrate that A. polyphylla does not germinate well at high temperatures. The trial was carried out at temperatures of $25^{\circ} \mathrm{C}$, $30^{\circ} \mathrm{C}$ and $35^{\circ} \mathrm{C}$.

Trial 3: This trial was to test whether other Aloe species germinated in the same conditions in which A. polyphylla was being trialled. The species trialled were $A$. castanea, A. branddraaiensis and A. elegans. 
A. castanea Schönland comes from the northern part of South Africa in the Transvaal where it grows in a climate that is very warm in summer and can reach freezing point in winter with an annual rainfall of 500-625mm (Jeppe, 1974). This species usually forms small trees from 2 to $4 \mathrm{~m}$ with many spreading branches higher up the main trunk. One of its other characteristics is its brown nectar after which it is named (Van Wik et al., 2003). Unlike A. polyphylla it thrives in hot sun and tolerates dry conditions quite well. It flowers in July and August (Jeppe, 1974).

A. branddraaiensis Groenewald is also endemic to Ohrigstad in Mpumalanga (Van Wik et al., 2003) where temperatures are higher and frosts seldom occur. It grows in warm sheltered situations and can flower multiple times throughout the year but mainly in June/July. Annual rainfall is the same (Jeppe, 1974). The flowers are stemless and clump-forming. It has a very localised distribution, growing on rocky hills and in the shade of bushes in Ohrigstad at $1,000 \mathrm{~m}$.

A. elegans Tod. is endemic to Eritrea and northern Ethiopia (Reynolds, 1966). It lives on rocky slopes of sandstone or limestone, in either evergreen bushland or wooded grassland at an altitude of $1,500-2,400 \mathrm{~m}$. The species is recognised by its grey/bluegreen incurved leaves. The flowers range from yellow through to orange and scarlet. It flowers in September-December (Denissew et al., 2010). According to Colin Walker (pers. comm., 2009), this species is considered to be a tropical aloe.

Trial 4: In this trial A. polyphylla was tested for germination at colder temperatures. The main aim was to further the cold treatments to replicate the colder chilling period which gave good results in trial 1. This may have been triggered by A. polyphylla and other species adapting to colder winters or night temperatures whilst in seed. This chilling requirement may be an adaptation and thus a possible secondary dormancy (Hartmann et al., 2002), which will be trialled further.

Trial 5: In this trial light requirements for germination were tested to see whether exclusion of light completely affected the germination of A. polyphylla. Light is one of the primary requirements for germination (Hartmann et al., 2002) of small seeds because the presence of light is an indication of proximity to the surface of the substrate. This is detected by photoreceptors in the seed which sense far-red light and red light, and is required by small seeds which do not have the reserves to grow through a deep layer of substrate. It is not known what level of lighting this species requires to germinate, either in quality (wavelength) or duration (photoperiod). For this trial seed was kept in the dark for 25 days. The polythene bags containing the seed were taken out of the black bags, placed on the window ledge and then sown in similar conditions to trial 1, to see whether there would be a period of dark-induced germination once seeds were brought out into the light again.

Trial 6: This trial was to demonstrate that sowing Aloe in conventional seed compost does not result in the germination of as many seeds as sowing in water-based media does. All four species previously trialled in this project, A. polyphylla, A. elegans, A. branddraaiensis and A. castanea, were tested. Germinating these seeds requires a constant source of water which is hard to maintain in soil-based media (Kofler, 1966). 
Trial 7: In this trial a preliminary test was carried out to see whether introducing extra oxygen into the water would increase the germination rate. The rationale for this was that being immersed in water reduces levels of $\mathrm{O}_{2}$. Seeds may germinate in an area of high water disturbance, thus increasing the amount of $\mathrm{O}_{2}$ present in the water (Kolta et al., 1989). Atmospheric $\mathrm{O}_{2}$ is 20 per cent; the concentration would probably be significantly reduced in water, thereby having an effect on the respiratory processes involved in germination (Hartmann et al., 2002).

Trial 8: Gibberellins play an important role in germination as they induce the activity of enzymes and activate the reserve food-mobilising systems which result in germination (Hartmann et al., 2002; Riley, 1987). Gibberellins have also been shown to replace the need for light and chilling to germinate seeds (Kozlowski et al., 1972). In this trial gibberellic acid $\left(\mathrm{GA}_{3}\right)$ was used in the water bag trials at varying concentrations to see whether this affected germination of A. polyphylla.

Trial 9: Research carried out by Toole (1941) suggests that nutrients, specifically potassium nitrate, can break non-deep physiological dormancies such as those involved in A. polyphylla. The objective of this trial was to narrow down the best fertiliser concentration for water media by using three more different concentrations as well as those which were used during this trial to see whether it had an effect on germination.

\section{SUMMARY OF RESULTS}

The results of the trials are noted briefly here. Tables of results are included where relevant.

\section{Trial 1}

The highest germination percentage results were gained from water-based media (distilled water, tap water and nutrient-based water); the best temperature treatment was chilling and then placing on a variable temperature to germinate.

The results gained from trial 1 proved to be crucial in investigating the germination technique being trialled in this study. From the first experimental design the following requirements were discovered for germination of A. polyphylla:

- Higher germination rates were achieved in water-based media compared with a soil-based media.

- A short chilling period $\left(10\right.$ or $\left.15^{\circ} \mathrm{C}\right)$ increased germination by up to $100 \%$.

- The best water-based medium for germination was the $10 \%$ fertiliser solution and distilled water. 


\begin{tabular}{|c|c|c|c|c|c|c|c|}
\hline \multicolumn{8}{|c|}{ Germination of Aloe polyphylla in different media and temperatures } \\
\hline \multicolumn{8}{|c|}{10 seeds per treatment } \\
\hline & $10^{\circ} \mathrm{C}$ & $15^{\circ} \mathrm{C}$ & $20^{\circ} \mathrm{C}$ & Window & $10^{\circ} \mathrm{C}$ Vern* & $15^{\circ} \mathrm{C}$ Vern* & Row totals \\
\hline \multicolumn{8}{|l|}{ Medium } \\
\hline Distilled water & 0 & 0 & 2 & 5 & 9 & 8 & 24 \\
\hline Tap water & 0 & 0 & 1 & 3 & 5 & 7 & 16 \\
\hline $100 \%$ fertiliser & 0 & 0 & 1 & 4 & 7 & 7 & 19 \\
\hline $10 \%$ fertiliser & 0 & 0 & 2 & 9 & 9 & 9 & 29 \\
\hline Moss & 0 & 0 & 0 & 0 & 2 & 3 & 5 \\
\hline Sand & 0 & 0 & 1 & 3 & 1 & 2 & 7 \\
\hline Seed compost & 0 & 0 & 2 & 0 & 0 & 3 & 5 \\
\hline Column totals & $\mathbf{0}$ & $\mathbf{0}$ & 9 & 24 & 33 & 39 & \\
\hline
\end{tabular}

* germinated seeds after being placed on window

Table 1 Germination results for trial 1.

Trial 2

Results showed that germination above $25^{\circ} \mathrm{C}$ does not occur in A. polyphylla.

\begin{tabular}{|l|l|l|l|l|}
\hline \multicolumn{5}{|c|}{ Germination of Aloe polyphylla at greater temperatures } \\
\hline $\mathbf{1 0}$ & $25^{\circ} \mathrm{C}$ & $30^{\circ} \mathrm{C}$ & $35^{\circ} \mathrm{C}$ & Row totals \\
\hline & \multicolumn{5}{|l|}{} \\
\hline Medium & 2 & 0 & 0 & $\mathbf{2}$ \\
\hline Distilled water & 2 & 0 & 0 & $\mathbf{1}$ \\
\hline Tap water & 1 & 0 & 0 & $\mathbf{3}$ \\
\hline $100 \%$ fertiliser & 3 & 0 & 0 & $\mathbf{2}$ \\
\hline $10 \%$ fertiliser & 2 & 0 & 0 & $\mathbf{0}$ \\
\hline Moss & 0 & 0 & 0 & $\mathbf{0}$ \\
\hline Sand & 0 & 0 & 0 & $\mathbf{0}$ \\
\hline Seed compost & 0 & $\mathbf{0}$ & $\mathbf{0}$ & \\
\hline Column totals & $\mathbf{8}$ & & \\
\hline Grand total seeds germinated: $8 / 210$ & &
\end{tabular}

Table 2 Germination results for trial 2. 


\section{Trial 3}

Three other species trialled showed similar germination responses to A. polyphylla as they germinated just as well, if not better, in water. However, they did not respond as well as A. polyphylla to a chilling period.

\section{Trial 4}

A. polyphylla chilled at $5^{\circ} \mathrm{C}$ did not give good results. Chilling at $10^{\circ} \mathrm{C}$ and $15^{\circ} \mathrm{C}$ proved to be better.

\begin{tabular}{|l|l|l|l|}
\hline \multicolumn{5}{|c|}{ Chilling of A. polyphylla at $5^{\circ} \mathbf{C}$} \\
\hline & Germinated & Not germinated & Row totals \\
\hline Medium & \multicolumn{3}{|c|}{} \\
\hline Distilled water & 8 & 2 & $\mathbf{1 0}$ \\
\hline $100 \%$ fertiliser & 0 & 10 & $\mathbf{1 0}$ \\
\hline $10 \%$ fertiliser & 0 & 10 & $\mathbf{1 0}$ \\
\hline Tap water & 4 & 6 & $\mathbf{1 0}$ \\
\hline Column totals & $\mathbf{1 2}$ & $\mathbf{2 8}$ & \\
\hline
\end{tabular}

Table 3 Germination results for trial 4.

\section{Trial 5}

This trial gave no results with zero germination.

\section{Trial 6}

A. polyphylla does not germinate well in soil-based media.

\begin{tabular}{|l|l|l|l|}
\hline \multicolumn{5}{|c|}{ Germination of trial aloes on seed-sowing compost } \\
\hline & Germinated & Not germinated & Row totals \\
\hline Species & \multicolumn{3}{|l|}{} \\
\hline A. polyphylla & 1 & 99 & $\mathbf{1 0 0}$ \\
\hline A. castanea & 70 & 30 & $\mathbf{1 0 0}$ \\
\hline A. elegans & 50 & 50 & $\mathbf{1 0 0}$ \\
\hline A. branddraaiensis & 11 & 89 & $\mathbf{1 0 0}$ \\
\hline Column totals & $\mathbf{1 3 2}$ & $\mathbf{2 6 8}$ & \\
\hline
\end{tabular}

Table 4 Germination results for trial 6. 


\section{Trial 7}

Results from this trial showed that increasing oxygen levels in water-based media did not improve germination further.

\begin{tabular}{|l|l|l|l|}
\hline \multicolumn{5}{|c|}{ Addition of oxygen to promote germination on A. polyphylla } \\
\hline & Germinated & Not germinated & Row totals \\
\hline Medium & \multicolumn{3}{|l|}{} \\
\hline Distilled water & 12 & 8 & $\mathbf{2 0}$ \\
\hline $10 \%$ fertiliser & 11 & 9 & $\mathbf{2 0}$ \\
\hline Column totals & $\mathbf{2 3}$ & $\mathbf{1 7}$ & \\
\hline
\end{tabular}

Table 5 Germination results for trial 7.

\section{Trial 8}

The application of GA3 did not enhance germination in A. polyphylla at either temperature.

\begin{tabular}{|l|l|l|l|}
\hline \multicolumn{5}{|c|}{ Effects of GA3 on A. polyphylla } \\
\hline Temperature: $21^{\circ} \mathrm{C}$ & Germinated & Not germinated & Row totals \\
\hline & \multicolumn{3}{|c|}{} \\
\hline Medium & 4 & 6 & $\mathbf{1 0}$ \\
\hline 100 ppm GA3 & 3 & 7 & $\mathbf{1 0}$ \\
\hline 200 ppm GA3 & 2 & 8 & $\mathbf{1 0}$ \\
\hline 300 ppm GA3 & 2 & 8 & $\mathbf{1 0}$ \\
\hline Control & 2 & $\mathbf{2 9}$ & \\
\hline Column totals & $\mathbf{1 1}$ & & \\
\hline
\end{tabular}

Table 6 Effects of different concentrations of giberellic acid (GA3) in parts per million (ppm) on germination of A. polyphylla at $21^{\circ} \mathrm{C}$.

\begin{tabular}{|l|l|l|l|}
\hline \multicolumn{5}{|c|}{ Effects of GA3 on A. polyphylla } \\
\hline Temperature: Window & Germinated & Not germinated & Row totals \\
\hline & & & \\
\hline Medium & 0 & 10 & $\mathbf{1 0}$ \\
\hline 100 ppm GA3 & 0 & 10 & $\mathbf{1 0}$ \\
\hline 200 ppm GA3 & 0 & 10 & $\mathbf{1 0}$ \\
\hline 300 ppm GA3 & 2 & 8 & $\mathbf{1 0}$ \\
\hline Control & $\mathbf{2}$ & $\mathbf{3 8}$ & \\
\hline Column totals & & &
\end{tabular}

Table 7 Effects of different concentrations of giberellic acid (GA3) in parts per million (ppm) on germination of A. polyphylla on window temperatures. 


\section{Trial 9}

The various solutions of nutrient-based water media do not directly affect the germination of A. polyphylla.

\begin{tabular}{|l|l|l|l|}
\hline \multicolumn{4}{|c|}{ Use of several fertiliser media on germination of A. polyphylla at $21^{\circ} \mathbf{C}$} \\
\hline Media & Germinated & Not germinated & Row totals \\
\hline $10 \%$ fertiliser & 4 & 6 & $\mathbf{1 0}$ \\
\hline $15 \%$ fertiliser & 5 & 5 & $\mathbf{1 0}$ \\
\hline $20 \%$ fertiliser & 3 & 7 & $\mathbf{1 0}$ \\
\hline $50 \%$ fertiliser & 6 & 4 & $\mathbf{1 0}$ \\
\hline $100 \%$ fertiliser & 5 & 5 & $\mathbf{1 0}$ \\
\hline Control media & 4 & 6 & $\mathbf{1 0}$ \\
\hline Column totals & $\mathbf{2 7}$ & $\mathbf{3 3}$ & \\
\hline
\end{tabular}

Table 8 Results from trial 9 at $21^{\circ} \mathrm{C}$ using varying solutions of Vitax@ nutrient fertiliser.

\section{DISCUSSION}

The results gained from trial 1 proved to be most useful in adding to knowledge about the germination of this species. Further trials would be necessary to achieve conclusive results. From the first experimental design the following requirements were discovered for germination of Aloe polyphylla:

- Higher germination rates were achieved in water-based media compared with a soil-based medium.

- A short chilling period $\left(10\right.$ or $\left.15^{\circ} \mathrm{C}\right)$ increased germination up to $100 \%$.

- The best water-based medium for germination was $10 \%$ fertiliser solution and distilled water.

According to research carried out by Jacot Guillarmod (1970), a very similar project was undertaken where the seed were set to chill in moist filter paper for a brief period of time (not specified) and then placed on a window to germinate. The water used was distilled water. She goes on to say that more than half germinated, which equals the results of the trial carried out here.

According to results from trials 1, 3 and 4, A. polyphylla did show improved germination when given a short chilling period then placed in a warmer position (in cases of $10 \%$ fertiliser there was $100 \%$ germination). The effects of alternating temperatures, which occurred when chilled seeds were placed on the window, did have a good effect on germination. An explanation as to why this occurred could be that the seeds contained abscisic acid (ABA) which was inhibiting germination (Milborrow, 1974), 
and giving seeds a chilling period decreases ABA activity, and thus the amount of ABA needed to inhibit germination, and increases the activity of GA3, with the result that the seeds then break their dormancy (Rudnicki, 1969). The results gained from trials 2, 5, 6, 7, 8 and 9 further corroborated that trial 1 was the best germination technique trialled in this study.

Taking into consideration results from this study the following dispersal techniques may occur in the wild which, in turn, would influence the germination of A. polyphylla:

- Ripened seeds, being very light, are deposited in the crown of the mother plant where water pockets among the leaves are present so seeds would germinate, giving a similar end result to viviparous germination. Chilling would occur (Jacot Guillarmod, 1969) during the wet season and nutrients would be present in the water as a result of decomposed leaf litter deposited in the crown. During the wet season, due to plants being near running streams (Kofler, 1965), water levels could rise to wash out the crown of the mother plant depositing the germinated seeds out of the crown and into the soil.

- The ripe, light seeds of A. polyphylla could get blown into the nearby water courses during the wet seasons. As they flow down the slopes they rehydrate and get deposited along the stream margins where they eventually germinate when a chilling period occurs in the wet season. This could explain why they are located near water courses (Kofler, 1965).

- The seed falls off the plant into the surrounding area in the soil. During the wet season the seeds lie rehydrating in puddles of water for a long period of time. Chilling occurs during snowfalls (Jeppe, 1974) and seeds germinate in the snow thaw with ample water supply.

- The final possibility is that seed-eating birds such as the grey-wing francolin (Francolinus africanus) or the helmeted guineafowl (Numida meleagris), which are found in Lesotho and are renowned for eating seeds (Avibase, 2009), eat the seeds on the ground around A. polyphylla. Once the bird has digested the seed and excreted it from its body, it germinates within the bird guano which contains nutrients and, with the help of a wet climate, it germinates.

Future trials could be further improved with the following recommendations:

- The chilling trial could have been further improved by varying the amount of chilling the seeds were subjected to. This was not possible, however, as there was not enough time or seeds to accomplish this.

- Another improvement would have been to ensure that the trials ran for equal lengths of time. This was not achievable because of travel restrictions - start and finish dates had to be arranged around the availability of transport.

- A nutrient test could have been done on all water-based media to analyse their 
content and the possible effects on germination. This was not carried out because of time restrictions.

- Not all trials contained a control; this was due to the scarce availability of seeds. Controls were used in what were considered to be the most significant trials.

- Other factors such as light and humidity could have been considered but according to wider literature on this species there was no account of those factors playing a major role in the germination of A. polyphylla (Beverly, 1998; Jacot Guillarmod, 1970).

\section{CONCLUSIONS}

With the results and facts gained from the work above, the following outcomes on germination trials for Aloe polyphylla were achieved:

Germination of A. polyphylla was possible by placing the seed in a clear, sealed polythene bag with any of the following media:

- distilled water;

- tap water;

- water containing a dilute amount of cactus or succulent feed (solutions of $10 \%$ and $100 \%$ proved best).

The bag should be half-filled and placed straight away in an area to chill $\left(10\right.$ to $\left.15^{\circ} \mathrm{C}\right)$ for two weeks and then placed on a warm, but not bright, window to allow germination. Seeds should be taken out once the radicle is visible to prevent rotting.

There is scope for work to be done in the future to improve knowledge of the germination of this plant. Examples include:

- investigation into the ecology of the plant and its relation with the surrounding flora and fauna;

- investigation into the chilling effects of the winter months on this plant: does the chilling break the seed coat or does it increase GA3 activity?;

- investigation into seed scarification on the plant with specific reference to replicating seed scarification after being digested by a bird (scarification in hydrochloric acid);

- improving the survivability of the plant in soil media once germinated (very low success rate in this report).

\section{REFERENCES}

AVIBASE (2009). Bird checklists of the world: Lesotho (online). Available at: http://avibase.bsceoc.org/checklist.jsp?region=ls\&list=howardmoore (Accessed: 22 June 2014). 
BEVERLY, A. (1979). My quest for Aloe polyphylla. Cactus \& Succulent Journal 51(1): 3-8.

BEVERLY, A.C. (1998). Aloe polyphylla Schoenland ex Pillans: the secrets of success. CactusAventures International 39: 9.

CHUKWUJEKWU, J.C., FENNELL, C.W. \& STADEN, J. VAN (2002). Optimisation of the tissue culture protocol for the endangered Aloe polyphylla. South African Journal of Botany 68(4): 424-429.

DENISSEW, S., NORDAL, I. \& STABBETORP, O.E. (2010). The Flowers of Ethiopia and Eritrea: Aloes and other Lilies. Shama, Addis Ababa.

GLEN, H.F. \& HARDY, D.S. (2000). Flora of South Africa, Vol. 5 (Part 1 - Aloaceae). National Botanical Institute, Pretoria.

HARTMANN, H., KESTER, D., DAVIES, JR., F. \& GENEVE, R. (2002). Plant Propagation: Principles and Practices, 7th edition. Prentice Hall, Upper Saddle River, NJ.

HEYWOOD, V.H., BRUMMITT, R.K., CULHAM, A. \& SEBERG, O. (2007). Flowering Plant Families of the World. Firefly Books Ltd., Richmond Hill, Ontario.

HORKWOOD, F.K. (1966). Aloe polyphylla cultivation in England. National Cactus \& Succulent Journal 21(2): 58.

JACOT GUILLARMOD, A. (1970). Notes on Aloe polyphylla. Basutoland Notes and Records 8: 30-36.

JEPPE, B. (1974). South African Aloes. Purnell \& Sons, Paulton.

KOFLER, L. (1965). The biology and cultivation of Aloe polyphylla, the spiral aloe. Journal of the Royal Horticultural Society 90(6): 250-255 (full information provided).

KOFLER, L. (1966). The biology and cultivation of Aloe polyphylla, the spiral aloe. National Cactus and Succulent Journal 21(1): 16-19 (overview of species, not detailed).

KOLTA, P., LANTOS, M. \& KEHRLI, J. (1989). Method for introducing and bonding gas into water, apparatus for carrying out the method and water produced by the method. Available at: http://www.wipo.int/pctdb/en/wo.jsp?IA=EP1988000948\&DISPLAY=STATUS (Accessed: 12 April 2009).

KOZLOWSKI, T.T., HILLEL, D., LEVITT, J., MCKELL, C.M., YOUNGNER, V.B. \& WAISEL, Y. (1972). Seed Biology. Academic Press, Inc., New York.

MABBERLEY, D.J. (2008). Mabberley's Plant Book. Cambridge University Press, Cambridge.

MARINELLI, J. (2004). Plant. Dorling Kindersley Ltd., London.

MILBORROW, B.V. (1974). The chemistry and physiology of abscisic acid. Annual Review of Plant Physiology 25: 259-307.

MOFOKENG, M.J. \& JIWEN, G. (2009). Conservation of endangered species: Aloe polyphylla in Lesotho. Environmental Research Journal 3(2): 68-75.

PILLANS, N.S. (1934). Plants - new or noteworthy. South African Gardening and Country Life 24: $267-268$.

PLANTZAFRICA (2002). Aloe polyphylla Schonl. ex Pillans. Available at: http://www. plantzafrica.com/plantab/aloepoly.htm (Accessed: 23 October 2008). 
REYNOLDS, G.W. (1966). The Aloes of Tropical Africa and Madagascar. The Trustees, The Aloe Book Fund, Mbabane.

REYNOLDS, T. (2004). Aloes: The Genus Aloe. CRC Press, London.

RILEY, J. (1987). Gibberellic acid for fruit set and seed germination. California Rare Fruit Growers Magazine 19: 10-12.

RUDNICKI, R. (1969). Studies on abscisic acid in apple seeds. Planta 86: 63-68.

SANBI (South African National Biodiversity Institute, South Africa) (2002). Available at: http:// www.plantzafrica.com/plantab/aloepoly.htm (Accessed: 23 October 2008).

TALUKDAR, S. (1983). The conservation of Aloe polyphylla endemic to Lesotho. Bothalia 14(3): 985-989.

TOOLE, V.K. (1941). Factors affecting the germination of various dropseed grasses (Sporobolus spp.). Journal of Agricultural Research 62: 691-715.

VAN WIK, B.E. \& SMITH, G. (2003). Guide to the Aloes of South Africa. National Botanical Institute, Pretoria.

WALKER, C. (2009). Personal communication. Confirmation of information can be obtained by contacting C.C.Walker@open.ac.uk 